Representation of Time in Typologically Different Languages: A Functional Approach

\title{
REPRESENTATION OF TIME IN TYPOLOGICALLY DIFFERENT LANGUAGES: A FUNCTIONAL APPROACH (BASED ON TURKISH, ARABIC AND CHINESE)
}

\author{
Sergii V. SOROKIN \\ Faculty of Oriental Studies, Kyiv National Linguistic University, \\ 73, Velyka Vasyl'kivs'ka St., Kyiv, 03680, Ukraine \\ sergii.sorokin@knlu.edu.ua
}

Mariia LYKHOSHERSTOVA

Department of Eastern Philology, Faculty of Oriental Studies, Kyiv National Linguistic University, 73, Velyka Vasyl'kivs'ka St., Kyiv, 03680, Ukraine mariia.lykhosherstova@knlu.edu.ua

Yuliia LIUBYMOVA

Head of the Department of Chinese Philology, Faculty of Oriental Studies, Kyiv National Linguistic University, 73, Velyka Vasyl'kivs'ka St., Kyiv, 03680,

Ukraine

yuliia.liubymova@knlu.edu.ua

\begin{abstract}
This research paper deals with the realization of time in three languages which belong to different linguistic types: inflected Arabic, agglutinative Turkish and isolated Chinese. The methodological framework of this research is the functional analysis method, the basic notions of which are the conceptual category and typical communicative situation. The paper aims to describe the principles of conveying temporal meaning by linguistic means and consequently the development of an "active" (or communicative) grammar of a certain language which is a grammar for the speaker. In the course of the research an inventory of linguistic means for the realization of time was made, the typology of communicative situations within the conceptual category of time was outlined, differences and similarities in conveying time in the three investigated languages were summarized and prospects for future functional research in Turkish, Arabic and Chinese were defined.
\end{abstract}

Keywords: Arabic language, Chinese language, Turkish language, functional approach, conceptual category, communicative situation, time, temporality, tense. 
Asian and African Studies, Volume 30, Number 2, 2021

\section{Introduction}

Time is a fundamental dimension of human existence. All people wherever they live and whatever languages they speak perceive time as a linear and continuous succession from a certain moment in the past, through the present, to the future. Being an ontological category, time both restricts and informs human existence. Time is a fundamental category of any human language (and one of the key categories of human thinking), since there is a diversity of means for conveying temporality in any language, and scholars have not found a single one without the means to represent time. Time (temporality) is chosen as an object of study more often than any other grammatical category. Even though time is a fundamental linguistic category, there are different ways to represent it in every language. It is quite evident that the diversity of linguistic means depends on the typological characteristics of a specific language and, as a result, on the character of linguistic thinking. This paper aims to determine the structural and functional features of time (temporality) in languages belonging to different linguistic types: agglutinative Turkish, inflected Arabic (characterized by internal inflection), and isolated Chinese. The subject of this paper is the semantic category of time (temporality) and the way various means of its expression function in the three given languages. In this research, we apply the method of functional analysis, which focuses on the functioning of different language means in the process of communication.

\section{Methods and Material}

Functionalism in linguistics has been one of the most popular and fruitful avenues of linguistic research for more than three decades. Among the variety of schools and trends of functional linguistics, we have chosen the methodological approach of the St. Petersburg school of functional grammar and its founder O. V. Bondarko. ${ }^{1,2}$ This approach is not so widespread in Western Europe but is often applied in the post-Soviet countries. The methodological principles developed in the works of the representatives of the aforementioned school of functional linguistics are based on the notion of the functional-semantic field as a system of linguistic means on various levels of a particular language used for conveying specific semantics (the so-called "semantic category") and a categorial situation as a variant of the realization of

${ }^{1}$ BONDARKO, A. V. Funktsional'naya grammatika [Functional Grammar].

${ }^{2}$ BONDARKO, A. V. (ed.). Teoriya funktsional'noj grammatiki: Temporal'nost'. Modal'nost' [Functional Grammar Theory: Temporality. Modality]. 
Representation of Time in Typologically Different Languages: A Functional Approach

an invariant semantic category. The results of functional linguistics research may be interesting from the contrastive point of view, especially when research involves data from typologically and genetically unrelated languages.

The research procedure of this study involves three steps, with a conceptual or notional category (semantic category, in terms of the St. Petersburg Functional Linguistics School) being a common platform of analysis and contrast (tertium comparationis). The basis of a conceptual category is rooted in extra-linguistic reality reflected in people's consciousness and thinking. Semantic categories can be nationally specific or culturally marked. Unlike "concepts" (in linguo-cognitive or linguo-conceptual meaning), for which ethnonational or cultural specifics is a norm, for a semantic category it is an exception. A semantic category that reflects relations between extra-linguistic objects is combined not with the presence or absence of objects themselves, but with the process of thinking, categorization. ${ }^{3,4}$ Contrastive semantic and grammatical studies based on unrelated languages give scientifically more significant results than investigations based on related languages that have a lot of similar ways of grammatical (or vice versa grammaticalized) representation of semantic categories. So, the first step is to define the semantic category which constitutes the basis of the research; in our paper it is the semantic category of time. The second step is to make the inventory of linguistic means (language tools) for the realization of a given semantic category. The third and foremost step of this study is to describe the functions of the inventory of linguistic means made at the previous stage.

In this case, the direction of the research procedure is of great importance. We understand that "classic" structural grammar gives us a description of semantics and, to some extent, the meaning of linguistic means, but it moves from linguistic means (forms) to their meaning (functions). This traditional "school" grammar belongs to a "passive" type and aims, first, at decoding a message. This type of grammar cannot be used for encoding and making a communicatively relevant message. As speech production moves from content (notion, the sense that a speaker wants to convey) to form, the basis for such functional description should be meaning. Consequently, our research proceeds from sense to form and from form to meaning at the first and second stages (singling out a semantic category as a research base and making an inventory of language means which can convey this category). At the main third stage the

${ }^{3}$ ROSH, E. H. Cognitive representation of semantic categories. In Journal of Experimental Psychology, 1975, Vol. 104, pp. 192-233.

${ }^{4}$ ROSCH, E. H. Principles of categorization. In ROSCH, E. H., LLOYD, B. B. (eds.). Cognition and categorization, pp. 27-48. 
direction is from meaning to form. The critical problem of the third stage is making a typology of semantic categories.

\section{Discussion and Results}

Following these methodological and theoretical statements, we will describe below the system of time representation in each of the three languages under analysis. It is clear that this paper does not provide a full description of the phenomenon; it is more a sketch for further detailed practical research which will finally develop into the material that we call "active" grammar.

\section{Time (Temporality) in Turkish}

\section{Inventory of Means and Structure}

Being an agglutinative language, Turkish has an elaborate system of grammatical means of expressing time. In general, it is done by the system of tense forms (absolute tense) and non-finite verb forms - verbal nouns, participles, and converbs (relative tense), having their specific morphological features (in Russian sources they are called affixes, in English - suffixes). The Turkish tense form system is specific for realizing absolute and internal time predominantly in a syncretic way, which, to some extent, resembles English tense forms. It is just syncreticity and not the lack of means for representing internal time, because the meaning of internal time can be differentiated by sense, for instance, by semic analysis.

The specific feature of the Turkish tense forms is their variability. Many forms seem to represent the same or almost the same things but may differ either in their way of representing internal time or at the level of subjective modality, which occurs more frequently. Subjective modality is the possibility of using this or that grammatical form, similar in meaning, depending on how the speaker interprets the situation. Look at the following examples for comparison. If the speaker views the present action as neutral, he / she uses the simple present tense (the Presence): Gidiyor - He goes / He is going, but if he/ she regards it as a habit the aorist is applied: Gider-He goes; if the speaker wants to deliberately present an action as ongoing, he / she uses the present continuous tense (the Progressive): Gitmektedir - He is going (He is in the process of going). Note that it is not so much the grammatical system, as is predominantly the case in English, as the subjective viewing of the speaker that regulates the usage of these forms. 
Representation of Time in Typologically Different Languages: A Functional Approach

A distinguishing characteristic of the Turkish tense form system is evidentiality, that is the ability of a tense form to represent an action as evident (a speaking person has seen the action he/ she is talking about for himself / herself, or he/ she has heard about it from reliable sources) and non-evident (a speaking person has not seen the action he / she is talking about for himself / herself, and he / she makes a judgment about this action from the words of some third person / persons or according to the result of some past action), for example: Geldi-He has come (or He came) means that "I saw his coming with my own eyes" or "I know from reliable sources that he has come"; Gelmiş - He has come (or He came) means that "I've heard from some other person(s) that he has come" or "I didn't see the process of his coming, but I see the result and most probably this result is unpredictable for me"; Gelecek - He is going to come; Gelecekmiş - He says he is going to come or Some other people say that he is going to come (and I am not sure that he is really going to). We will discuss these different nuances in the meaning of temporal communicative situations below. All the Turkish tense forms, as well as many of the mood forms, have the possibility of non-evidential usage. The suffix of this form is $m i s$, as we can see in the examples above.

The Turkish language has five simple tenses (the present tense, the past tense/ definite past (di-past), the non-evident / reported / inferential past (mişpast), the aorist/ general tense, the present and future tense); two non-standard tense forms: the present continuous and the future perfect (going-to future). These forms are considered to be non-standard because all the simple tenses are participial in origin (it resembles the structure of English continuous or perfect forms which constitute the compound of a copula and a participle), and only these two forms are substantival in origin.

Along with the simple, there are compound forms made from the simple ones by adding predicate suffixes (three out of the four suffixes mentioned can be used to make compound forms). All the compound forms have three semantic levels: the evident (marked by the suffix -di), the non-evident (marked by the predicate suffix -mış), and the conditional (marked by the predicate suffix $-s a$ ). The aorist can be taken as an example for comparison: a) the aorist yapar (yap-is the base of the verb "to do" and -ar is one of the suffixes forming the aorist) - He does; yapard (we can see the formant $-d l$ which, being added to a simple tense form, marks the evident level) - He did or He would do; yaparmıș (we can see the formant -mıș which marks the non-evident level) - He says/ he is said to do/ to have done; yaparsa (we can see the formant -sa which marks the conditional level) - If he does... Any simple and both non-standard tense forms, as well as the necessitative mood, may acquire these features, forming the compound forms that have similar meaning with one of the abovedescribed levels. 
To conclude, the Turkish language has nine evident and non-evident compound tense forms, five simple forms, and five compound conditional tense forms, making nineteen in all. Moreover, there are complex tense forms (the socalled Katmerli Bileşik Zamanlar, the Turks call them "multilayer" because, in these forms, the evident or non-evident levels are overlaid with the conditional level; as a result, the conditional predicate suffix is added to the compound tense form). The nine complex tense forms can only be conditional. Furthermore, there are two non-standard tense forms (mentioned in the previous paragraph), also having the evident, non-evident, and conditional levels (eight all in all) and, hypothetically, two complex conditional forms. Finally, having calculated all the above mentioned forms, we can state that there are 38 tense forms in Turkish (though this data varies in different sources. ${ }^{5}$ We should consider the evident, non-evident and conditional levels of verb mood (if possible), and periphrastic forms, that can specify the internal-time characteristics of an action (more on this below). We can see that the Turkish tense system is quite elaborate, first, from the structural point of view.

On the other hand, there are tense forms that have a high frequency of usage (simple tenses, the vast majority of compound tense forms of the evident and conditional levels), and there are some that are "exotic" even for native speakers (for example, the non-evident pluperfect with the set of suffixes -mışmış or the vast majority of complex conditional forms) that one may not encounter over a whole lifetime. The stylistic parameter of tense form usage is also of great importance: some of them (and their combinations) occur primarily in texts of particular functional styles: either in colloquial speech or, conversely, in texts belonging to scientific-technical or official documents styles. Due to the format of this article, it is impossible to enumerate all the verb tense forms, but in the Turkish sources we may come across tables and schemes that represent almost all (with minor exceptions) tense forms, distinguished according to the scheme that this research is based on. ${ }^{6}$ Note that the schemes for structuring Turkish tense forms differ according to the research approach. That is the reason why in Russian sources non-evident and conditional rows of tense forms are not differentiated, but the so-called category of grammatical modality is given instead. $^{7}$

The tense forms set out above represent external (absolute or relative) and internal time syncretically. At the same time, there are a variety of forms in Turkish that can specify both internal-time and modal characteristics of a verb

\footnotetext{
${ }^{5}$ LEWIS, G. Turkish grammar, p. 136.

${ }^{6}$ HENGIRMEN, M. Turkish grammar, p. 237.

${ }^{7}$ SHCHEKA, Y. V. Prakticheskaya grammatika turetskogo yazyka [Practical grammar of the Turkish language], pp. 182-236.
} 
Representation of Time in Typologically Different Languages: A Functional Approach

irrespective of its grammatical form. Traditionally they are defined as "periphrastic forms" and constitute a combination of participle and auxiliary verb olmak / bulunmak. A periphrastic form can discretely convey such characteristics of an action as resultativity, intention, beginning or ending, etc., irrespective of the verb form (that is, such differentiation of meanings can be applied even at the level of the infinitive as in the example gelmis olmak - to be such, that has come).

There is no doubt that the general data set out above give us only a vague idea of the system of Turkish tense forms, but this idea is enough to understand the crucial point: there are many ways of expressing separate sense aspects of time in the Turkish language, and even to unambiguously structure them is not always possible. Having described the variety of formal means, we will try to answer the key question of our research: what are the typical communicative situations that the Turkish language means of expressing time are realized in.

\section{The Functioning of Means of Expressing Time in Turkish}

The time (temporal) communicative situations within a semantic category are grouped according to the main parameter: the relation of an action to the moment of speaking or some reference point in the past. Using this parameter, all communicative situations are divided into five layers or frames: 1) the present tense frame (including the moment of speaking); 2) the past tense frame (the action took place before the moment of speaking); 3) the future tense frame (the action is going to / planned to take place / may / has to take place after the moment of speaking); 4) the past perfect (pluperfect) tense frame (the action took place before some moment in the past); 5) the future perfect (going-to future) tense frame (the action will take place before some moment in the future or after the moment of speaking).

Note that the purely communicative parameters are overlaid with formal parameters, which is hard to avoid while describing linguistic means. There are two parameters of the kind: 1) stylistic parameters of using grammatical forms (as mentioned above, there are forms that cannot or almost cannot be used in the texts of definite functional styles); 2) syntactic parameter (from the communicative point of view, it is not that important in what way an action is syntactically marked, but from the formal point of view it is significant whether the verb form denoting an action is the main part of an utterance (predicate) that the whole sentence is based on, or the secondary part, syntactically "connected" to some other verb in the sentence; in the first case the communicative situation is encoded by finite verb forms, in the second case by non-finite ones. Functional (or functional-communicative) language description is impossible 
without taking into consideration the formal and structural features of a language because in no language is everything connected with functioning. Most phenomena have a formal, often non-motivated character, which is why even an active grammar must be formal-structural in many cases. Below there is a possible descriptive framework of the expression of time in the Turkish language, based on the parameters mentioned above. A detailed description of the expression of time may be presented in the form of a monograph; such description is among the aims of our further studies. It refers to each of the three languages that are the subject of our investigation. This article deals only with the communicative situations, verbalized by finite (tense) verb forms that syncretically convey absolute and internal or relative and internal time; this paper does not deal with relative time realized by non-finite verb forms or with internal time when it is expressed autonomously.

The present tense frame. It is quite apparent that for a person the moment he / she is in (the moment of speech / communication, the "here and now") is the key one in the cognitive and linguistic systems, and it is this very moment that the whole verb system is oriented towards. If we compare how Russian or Ukrainian speakers understand present action, we will see that their perception of the present is univocal regardless of any other factors. The present action is always in the present period in time and is expressed by only one tense form (of course, it is possible to express present action metaphorically, for example, by the past tense in the narrative, but this paper only deals with standard situations). The way Turkish people understand the present is much more complicated. Below we will describe the typical communicative situations and the peculiarities of their representation using the Turkish language.

An action happening at the moment of speaking. Such an action is always realized by the simple present tense, e.g., Kitap okuyorum - I am reading a book. However, the only exception to this rule is the situation when the speaker highlights the processuality of the present action, i.e., deliberately presents the situation as ongoing (this case will be elaborated on below).

An action happening in the present (broad) period in time, not necessarily at the moment of speaking. That is the present action being realized "around" the moment of speaking, and it is of minor importance: a) whether the action is taking place at the time of speaking; b) how long the action has been in progress (today, this week, this month, this year, etc.). Such an action is also realized by the present tense, for example, Bu hafta tenis oynamiyorum - I am not playing tennis this week. Bu yll çok ağır çalışıyoruz - We are working hard this year. An exception to this rule may be the situation of representation of such an action in official documents and technical texts, which instead of the simple present tense uses either the aorist or the present continuous tense, as in the sentence Khartsizsk Boru Fabrikasinda her yıl 500000'nin üstünde büyük çap 
Representation of Time in Typologically Different Languages: A Functional Approach

çelik boru üretilir / üretilmektedir - Over 500,000 steel pipes of large diameter are produced at the Khartsyzsk Pipe plant every year. Note that according to the modern Turkish linguistic norm, the simple present tense is not to be used in official documents and technical texts, though in practice it does occur from time to time.

An action deliberately presented by the speaker as ongoing. This kind of action appears as a result of the speaker's subjective interpretation of the situation; it happens quite rarely, and completely overlays both communicative situations described above. Thus, if a speaker wants to represent a situation taking place at or "around" the moment of speaking he / she may use the present continuous tense (the progressive) and especially highlight the processuality of the action, as in the sentences Günlerce kitap okumaktadır - He reads books every day (from morning until night). Yeni proje üzerinde çalışmaktayız - We are working on a new project. This tense is commonly used in official / formal communication (primarily written) although it is sometimes also used in official texts. The duration of action can also be emphasized by the so-called analytical verbs (Tüm gece kitap okuyup duruyor having the same translation), but they constitute a separate object of research.

A timeless action. Such a situation relates to the representation of eternal truths (the so-called gnomic present tense). It is an action denoting a general truth without reference to time, e.g., Balıklar suda yaşar - Fish live in water. Insan doğar, yaşar, ölür - A person is born, lives, dies. A timeless action can only be expressed by the aorist, and no other present tense forms can be used for this purpose.

An action that is traditional for a given language community. The current and the following communicative situations constitute the result of further development of the previous situation and are marked predominantly by the aorist, for example, Ukrayna'da günde 8 saat çalışılır - In Ukraine people work 8 hours a day. It must be stressed that according to the modern Turkish linguistic norm, the simple present tense may also be used to represent this communicative situation, though it hardly ever occurs. Note that, when a tradition is presented (actions that are traditional for a given society, community), the passive predicate and the aorist are preferable; because in Turkish, it is the passive that is used to express an indefinite action (see the example above).

A regular activity that is an individual habit. This situation resembles the latter one, though in contrast to the previous situation representing the tradition of a group of people, it displays an individual habit that is regularly observed at some (broad) period. In modern Turkish, both the aorist and the simple present tense (presence) are equally used to express such an action, and it is impossible to draw a line between them. The general rule says that an objectively induced 
action should be marked by the aorist, but it is the speaker who decides to what extent it is subjective or objective (remember "the human factor in a language"), compare, for example, Ahmet çok sigara içer - Ahmet çok sigara içiyor - Ahmet smokes a lot. İsyerime otobüsle giderim - İsyerime otobüsle gidiyorum - I get to work by bus.

The past tense frame. In the past tense, the key semantic contrast is between a) a fact (an action is represented as a fact) and an ongoing action (represented as a process); b) an evident action (evidential) and a non-evident action (non-evidential).

A past evident action represented as a fact. It is a single, repeated or continuous action that took place before the moment of speaking and is represented as a fact. It is not relevant whether the action relates to the moment of speaking, but the speaker must have witnessed the event, or his / her opinion is based on reliable sources. Such an action is always expressed by the categorical past tense, e.g., a) a single action: Dün bir bilimsel makale okudum Yesterday I read a scientific article; b) a repeated action: $\ddot{U} c ̧$ defa kapıyı vurdum - I knocked on the door three times; c) a continuous action, represented as a fact: Geçen hafta okula gelmedim - I did not come (or I wasn't coming) to school last week. This situation is particularly difficult for Slavonic speakers learning Turkish as a foreign language because in Slavonic languages there is a perfective - imperfective grammatical opposition. In contrast, in Turkic languages even an ongoing action may be represented as a fact, resulting in the incorrect use of the simple present and imperfect tense forms.

A non-evident past action. This action has similar characteristics with the latter one with the exception that the speaker has not witnessed it happening, and his / her opinion is based on other sources. It is expressed by the nonevident / inferential past tense, as in the sentences Ahmet dün bir bilimsel makale okumus - They say / Ahmet says / Ahmet is said to have read a scientific article yesterday. Geçen hafta okula gelmemişsiniz - You are said / they say that you did not come to school last week.

A past action unexpected for the speaker. A past unexpected action that the speaker has not witnessed (it turned out that), it may additionally be underlined by the particle meğer. This situation is expressed by the non-evident (-mış) past tense, as in the sentence Ben uyurken kar yağmıs - It turned out that while I was sleeping it was snowing (everything is covered by snow).

A past action inferred by the speaker form the result. It is a past action that was not directly observed or was inferred by the speaker, e.g., Gece kar yağmış - It snowed at night. Çok güzel çizmişsin - You painted it very well (I have not seen the process of snowing or painting). The three preceding communicative situations are connected by non-evidentiality: the speaker has not seen when the 
Representation of Time in Typologically Different Languages: A Functional Approach

action was taking place, and his/her opinion is based on other sources: someone's words or the results, which may be unexpected / surprising.

A past resultative action. In contrast to English that differentiates the actional and statal perfect tenses, for literary Turkish based on the Istanbul dialect, the category of the perfect is not relevant. Nonetheless, for the Eastern, a part of North Eastern and South Eastern Turkish dialects that constitute a dialect continuum with the Azerbaijani language, the representation of this communicative situation is often relevant. ${ }^{8}$ The abovementioned non-evident ($m ı s)$ past tense is historically the Oghuz perfect. In modern Turkish its "perfectivity" is preserved in a number of forms, mainly in the past participle (okunmus kitap - a read book, çevrilmiş makale - a translated article). In contrast to literary Turkish where the perfective meaning in the past tense form was displaced by non-evidentiality or inference, it is still preserved in the Azerbaijani language, and, consequently, is often used in dialects close to Azerbaijani as the statal perfect, e.g., Spil Dağı milli park haline getirilmiş Mount Spil has been turned into a national park. This form plus a third person singular predicate suffix constitute a tense form (that is not usually distinguished) used in official document texts (predominantly written). Sometimes it is called the past historical tense, but its functions and correlation with other tense forms are the subject of separate research, e.g., Türkiye Cumhuriyeti 1923 yllinda ilan edilmiştir - The Republic of Turkey was proclaimed in 1923.

An action that was in progress at some moment in the past. In this case, we use the definite imperfect, which is formally the present tense, shifted into the past. It is an action that was in progress at some moment in the past, and may have some direct or indirect (contextual) indicators, e.g., Dün bu saatte parkta oturuyor kitap okuyordum - At this time yesterday, I was sitting in the park and reading a book. Very often such past continuous action is a background event for another past action, e.g., Parkta dolaşlyordum derken karşıma koskocaman bir çoban köpeği çıkmasın mı! - I was walking in the park and was suddenly attacked by a huge sheepdog! It is interesting to know that if the period in time during which the action was in progress is indicated, there is no need to use the imperfect form: Beş yll bir fabrikada çalıştım - I have been working at the factory for five years. Probably, in the Turkish syntax system, the double indication of duration is perceived as a grammatical pleonasm; on the other

\footnotetext{
${ }^{8}$ SOROKIN, S. V., TIMKOVA, T. M. Problems and difficulties in teaching Turkish grammar to Ukrainian students at university level. In Journal of History Culture and Art Research, 2019, Vol. 8, No. 4, pp. 90-114.
} 
hand, it was mentioned above that even an ongoing action represented as a fact could be marked by the simple present tense.

A traditional or habitual past continuous action. A past continuous action that used to be an individual habit, the tradition of a society or language community is marked by the indefinite imperfect tense, which is formally the aorist shifted into the past, as in the sentences Illkel insanlar mağaralarda yaşarlardl - The first humans lived / used to live in caves. Dedem akşamlarl bana masal anlatırd - My grandpa would tell me tales in the evenings. The cases of using the definite imperfect tense instead of the indefinite are quite rare, whereas the opposite is a mistake.

A past action deliberately presented as an ongoing. This situation may be conveyed by the past continuous tense, which is formally the present continuous tense (the progressive) shifted into the past. It is used either subjectively (if the speaker wants to deliberately highlight the processuality of the action in the past) or in official / formal speech, e.g., 1991 yllina kadar fabrikada yılda 1000000 çelik boru üretilmekteydi - (as in the present tense frame, it is possible to substitute the past continuous tense for the indefinite imperfect: üretilirdi) Till 1991 the plant produced 1 million steel pipes.

A future action from a past reference point. This situation denotes an action that was to / could have taken place in the future in relation to a past reference point. It is conveyed by the future-in-the-past tense which formally is the future categorical tense (the futurum) shifted into the past, and it is not relevant whether the situation happened or not (according to the context, it probably has not), for example, Futbol maçına gidecektik, hava koşulları nedeniyle maç iptal edildi - We were about to go to a football match, but it was cancelled due to weather conditions.

The past perfect (pluperfect) tense frame. In Turkish, the use of past perfect tense markers is not so strictly regulated as, for example, in English, but still, there are two typical communicative situations in this frame, and only one of them relates to the past perfect action indication.

A past action completed before another past action. This past action is oriented towards another past action on the timeline, i.e., it took place before another past action, and is either connected with it by the result or not. Such situation is portrayed by one of the two pluperfect (past perfect) tenses, called the pluperfect I (marked by the suffix -mışt and common to literary Turkish) and pluperfect II (marked by the suffix - dlyd $\iota$ and most common in some Black Sea Region dialects), for example, Güzel bir bungalova yerleştik, her tarafi çiçeklerle süslenmişti - We stayed at a beautiful bungalow, everything around us has been decorated with flowers.

An action "moved" by the speaker into the past perfect period in time. In fact, this communicative situation is not the past perfect, as it is oriented 
Representation of Time in Typologically Different Languages: A Functional Approach

towards the moment of speaking instead of another past action. The speaker uses the pluperfect form as a stylistic marker, trying to verbally "move" the situation further back in time. It can be seen in the form of a polite reminder; in this case, the speaker may also use the particle hani, e.g., Hani sana beş bin dolar vermistim? - Do you remember that I lent you 5 thousand dollars?

The future perfect (going-to future) tense frame. There is only one communicative situation in this frame, and it is rarely used in speech. A state of being ready to perform the future action is expressed by a combination of means: the infinitive and the postposition üzere (-mak üzeredir). In contrast to other tense forms, this compound form is nominal, and it is arguable as to whether it should be included in the tense form system. However, this combination belongs to the means of expressing, for example, Dikkat, dikkat, İstanbul - Ankara Ekspresi birinci perona girmek üzeredir - Ladies and gentlemen, pay attention, please! The express train from Istanbul to Ankara is arriving on track 1.

The future tense frame. In the Turkish language, both the typology of communicative situations representing a future action and the system of grammatical means for their expression are quite elaborate in contrast to Chinese and Arabic. In many languages, the system of notions and grammatical means to convey a past action prevails over a future one.

A future action planned according to timetables and schedules. It is an action expressed primarily by verbs of motion. It can be observed in many languages, for instance, English, Ukrainian, or Russian. When it comes to action (movement) planned in accordance with timetables, schedules, etc., the present tense is used, as in the sentence Annem yarin Lviv'den geliyor - My mother is coming back from Lviv tomorrow. Tren kaçta hareket ediyor? - What time does the train leave?

A future action planned in advance or logical action. Such a situation is one of the two most common in the Turkish language (along with future potential action); this action is expressed by the future tense (sometimes called the future categorical tense), indicated by the suffix -acak, for example, Issi ne zaman bitireceksiniz? - When will you finish / are you finishing your work?

A future possible (potential) action. This situation is contrasted to the latter one as a potential action to a planned one; along with evidentiality, described in the past action frame, the division of communicative situations connected with the future action into two parts: planned and potential actions are often difficult for learners of Turkish who do not have such a differentiation in their native language. Compare these examples: Bu işi yarın bitireceğiz - We will finish (plan / are going to finish) this work tomorrow. Bu işi yartn bitiririz - We will finish (may finish) this work tomorrow. 
Spontaneous wish to act ("action as an urge"). One's wish to perform an action that spontaneously arose at the moment of speaking is expressed by the forms of the wish mood (it predominantly refers to the first person singular and plural); and is indicated by the suffix -a/ -e, for example, Kahve içeyim - I will have some coffee. Sinemaya gidelim - Let's go to the cinema.

A suggestion and desire to act. In modern Turkish, a wish and suggestion to realize it are often expressed by the conditional mood forms (the "wishconditional" in Turkish grammar terms), for example, Hanımefendi, elma alsanız - Lady, why don't you buy some apples. Bir fincan kahve içsem - I'll have some coffee.

Every communicative situation described above is more detailed in reality, and there can be many more communicative situations. What is given here is only a framework description of the Turkish verb tense system. It should be noted, that the vast majority of the given communicative situations may also be non-evidential (i.e., the speaker's opinion is inferred) and marked by the nonevident predicate suffix -mış (e.g., Yarın gelecekmiş - He says / is said to come tomorrow. Lviv'de yaşlyormus - He is said (he says) to live in Lviv. Fransa'da haftada otuz saat çallşllırmış - They are said to work 30 hours a week in France). A lot of communicative situations may be complicated by the modality of statement and supposition (kuvvetlendirme ve ihtimal), marked with the predicate suffix -dir (for example, Yartn gelecektir - He must (is to) come tomorrow); consequently, almost any of these communicative situations may be complicated by the conditional modality by adding the conditional predicate suffix -sa/ -se to the "common" tense forms (for example, geliyorsa - if he comes; gelirse - if he comes (in the future); geldiyse - if he came; gelmişse - if he had already come; gelecekse - if he decides to come; geliyormusssa - if, as he is said, he comes).

It should be noted that the three types of modality mentioned above have direct grammatical (suffixal) expression, which is why the Soviet and PostSoviet Turkic school differentiates the declarative, subjective and conditional grammatical modalities. In Turkish grammatical works, two of the three given components are described as modal modifications of tense forms: rivayet, şart, in contrast to the evident modality level hikaye; the declarative modality stands out of the formal-systemic restrictions as a phenomenon called kuvvetlendirme ve ihtimal (statement and supposition). Every tense form may be complicated by the non-evidential (except the past categorical tense) and conditional modalities, and many of them by the declarative and suppositional modalities, increasing the number of typical communicative situations conveyed by the Turkish tense form system by a few times. There is no doubt that from the "active" grammar point of view, each such case should be described as a 
Representation of Time in Typologically Different Languages: A Functional Approach

separate typical communicative situation, and such a description will take dozens of pages.

\section{Time (Temporality) in Modern Standard Arabic}

\section{Inventory of Means and Structure}

Arabic is a fusional language, characterized by internal inflection and a quite extensive system of grammatical means of expressing time. First of all, it has a system of tense forms, complex tense constructions (absolute and relative time) and non-finite verb forms - participles.

It is important to mention that depending on the stages of development (Classical Arabic Language of VII - IX centuries or Standard Modern Arabic) verb forms changed their semantics. It can be said that the typical feature of the main forms of verb conjugation in the Classical period of the language's development is that in the forms fa'ala-yaf'alu the concept of aspect had a clearer expression than the concept of time; both forms of verb conjugation do not have a distinct temporal characteristic and can represent present, past and future times. ${ }^{9}$

Gradually, the concept of time was established in the main forms of the verb in Arabic and merged with the concept of aspect very closely. Denoting both aspect and time, the forms $f a$ 'ala $-y a f^{\prime}$ alu are bifunctional in nature ${ }^{10}$, and over time the category of temporality in Arabic has developed and intensified. Beeston ${ }^{11}$ argues that the Arabic verb has three characteristics: temporality, aspectuality and modality but in practice one of them "overshadows" the other two. So in Modern Standard Arabic the form fa 'ala denotes the action that precedes the moment of speech, and the aspect of completeness (incompleteness) of the action in many cases is determined by the context and depends on the general speech situation. As to the form yaf'alu, in Modern Standard Arabic it signifies uncompleted action in the present and future.

In the grammarians' works on the Arabic tense forms, especially the analytical ones, there is no uniform terminological definition, and they did not

9 MAMEDALIYEV, V. M. Ogly. Kategoriya vremeni, litsa $i$ nakloneniya $v$ sovremennom arabskom literaturnom yazyke kommunikatsii [The category of time, person and mood in the modern Arabic literary language of communication].

${ }^{10}$ FISCHER, W. Classical Arabic. In HETZRON, R. (ed.). The Semitic languages, p. 207.

${ }^{11}$ BEESTON, A. F. L. Written Arabic: An approach to the basic structures, pp. 49-50. 
receive a clear systematic description. However, according to $\mathrm{Grande}^{12}$, they can to some extent be compared with the complex tense forms (constructions) of other languages. In our research, we will follow this approach, since in this way we will try to express in the terminological definition not only the reference of verb forms to a certain time plane, but also the aspectual meaning (completeness / incompleteness, duration), relative time. We do not seek to achieve the ultimate unification of the terminological definition of the system of tense forms in the Arabic language, but we hope that the terminology given below will help us better understand the semantics of verb forms.

Arabic has three simple tense forms, namely the Present Simple Tense, the Past Simple Tense and the Future Simple Tense. At the same time, there is no separate morphological form of the Future Simple Tense and the future is expressed by the use of the form of the present simple tense yaf'alu with the addition of the conjugate particle $s a$ - or the separate particle sawfa. However, since the usage of the abovementioned sa- (sawfa) yaf'alu has the specific meaning of the future, we consider it a separate form in our research. Also, there are seven complex tense forms (constructions) (note that the number of tense forms (constructions) in the Arabic language varies depending on the theoretical approach of the researcher, so we can see other possible numbers mentioned).

So, in the present frame, besides the present simple tense form yaf'alu, there are complex tense constructions of the present possible tense - qad yaf'alu, and the tense construction lam yaf'al ba ' $d u$, which in some way can be called the present perfect tense, because it has the specific meaning of the incompleteness of the action that has a connection with the present and corresponds to English have / has not yet. Both forms are quite rare.

The past plane is represented by the following complex tense constructions: the past continuous tense - kanna yaf'alu; the past perfect tense (or the pluperfect) - kāna (qad) fa 'ala; the future-in-the-past tense - kāna sa-yaf'alu. As we can see, the auxiliary verb kana, which is in the form of the past tense and relates action to the past, is common to these temporal constructions.

In the future plane, besides the future simple tense form, which is essentially a form of the present simple tense $y a f^{\prime}$ alu with the addition of the conjugate particle $s a$ - or the separate particle $s a w f a$, there are such temporal constructions as the future perfect tense (sa)yakūnu fa'ala / qad fa'ala and the future continuous tense yakūnu yaf'alu. The auxiliary verb yakūnu in both cases is in the form of the present simple tense, sometimes used with the specifying

${ }^{12}$ GRANDE, B. M. Kurs arabskoj grammatiki v sravnitel'no-istoricheskom osveschenii [A course of Arabic grammar in comparative-historical interpretation], pp. 158-159. 
Representation of Time in Typologically Different Languages: A Functional Approach

particle of the future $s a$-, indicates the future tense frame, and a semantic verb, depending on its form, indicates completion or duration.

Despite the large number of complex tense constructions, simple tense forms fa'ala - yaf'alu have a high frequency of usage, and complex tense constructions are extremely rare, some (such as the future-in-the-past tense) may not occur at all. At the same time, the stylistic aspect of the usage of tense forms in the texts of specific functional styles is also important.

The above data give us only a very general idea of the system of Arabic tense forms, but this is sufficient to understand that there are a considerable number of means in Arabic to indicate various aspects of time. We now need to examine the typical communicative situations in which the aforementioned linguistic features of Arabic are used.

\section{The Functioning of Means of Expressing Time in Modern Standard Arabic}

Considering the analysed inventory of means of expressing time in Modern Standard Arabic, it is possible to divide communicative situations into five frames: 1) the present tense frame (including the moment of speech); 2) the past tense frame (the action took place before the moment of speech); 3) the future tense frame (the action is going to / planned to take place after the moment of speech); 4) the past perfect (pluperfect) tense frame (the action took place before some moment in the past); 5) the future perfect tense frame (the action will take place before some moment in the future).

The present tense frame. Numerous studies of the present tense in different languages prove the universal semantic essence of the central form of the present, when the relation of the situation to the moment of speech is one of the main meanings of these forms, but it is not invariant. It is this "wideness" of the present tense frame that causes this form to function as the historic present, actual present, present in the context of future, etc. Below we will describe the typical communicative situations in the present tense frame and their implementation in Modern Standard Arabic.

An action happening directly at the moment of speech. In this case it is emphasized that the action takes place at the moment of speech, for example: mā $\underline{d} \bar{a}$ taf'alina al-'ān? - What are you doing now? Therefore, the verb form of the present simple tense yaf'alu is always used to express such an action. It is worth mentioning that when expressing the action taken at the moment of speech, the personal form of yaf'alu simultaneously indicates its continuous, 
imperfect character ${ }^{13}$, which is quite usual for the action occurring at the moment of speech.

An action that begins at the moment of speech and takes place immediately after this moment. Such an action is always realized by the present simple tense yaf'alu; the time of the action is quite short, for example: al-yawma lā 'ašrabu al-qahwa, al-šāy faqat - Today I'm not drinking coffee, only tea.

An action is regular (permanent), an individual habit, or inherent to the subject in general. Usually this action expresses a habit which is regularly (permanently) performed and realized by the present simple tense yaf'alu, for example: ya 'malu 'abì fì al-mașna' al- 'askarī-My father works at a military factory.

An action that will take place in the near future according to a timetable, arrangement, etc. It is expected that such an action will definitely happen, and therefore the future seems to be approaching the present. In this case, the form of the present simple tense yaf'alu functions, not the future simple tense sayaf'alu. For example: 'adhabu 'ilā Mișr fì al-šahr al-tālī-I am going to Egypt next month.

The form of the present simple tense yaf'alu expresses both present and future. However, the first function, which is minimal in context, appears as the main meaning of this form. The referring of the action to the future is more due to the context and lexical means. Moreover, in Arabic, there is a special grammatical form sawfa yaf'alu - sa-yaf'alu, which has the function of expressing future with minimal context.

An action unfinished by the moment of speech. In Arabic, to express this communicative situation there is a separate specific temporal construction lam $y a f^{\prime} a l . . . b a$ ' $d u$, which has the meaning of the incomplete action connected with the present and which corresponds to the English present perfect tense have / has not yet done. For example: lam yadrus wäjiba-hu al-manziliya ba'du-He has not studied his homework yet.

A present possible action. Such a communicative situation is expressed by the form of the present simple tense yaf'alu, preceded by the particle qad. It has the function of expressing a possible or probable action. ${ }^{14}$ This form is very rare: qad yudfa 'u al-šarr bi-mițli-hi 'id̄a 'a 'yā-ka gayru-hu - Evil can be defeated by

\footnotetext{
${ }^{13}$ ALASMARI, J., WATSON, J. C. E., ATWELL, E. A contrastive study of the Arabic and English verb tense aspect: A corpus-based approach. In PEOPLE: International Journal of Social Sciences, 2018, Vol. 3, No. 3, pp. 1604-1615.

${ }^{14}$ KHRAKOVSKIY, V. S. Vidovremennyye otnosheniya $v$ sisteme lichnykh form glagola $v$ arabskom yazyke [Aspectual and temporal relations in the system of personal verb forms in the Arabic language], pp. 15-16.
} 
Representation of Time in Typologically Different Languages: A Functional Approach

his kind if you are tired of the other way (a good one). More commonly mentioned construction indicates an action that just takes place in the present.

The past tense frame. The past is expressed differently in typical communicative situations (in our case in Turkish, Arabic and Chinese), imparting shades of nationally specific awareness of the temporal structure of reality by native speakers of different languages. Below we will describe the typical communicative situations in the past tense frame and their implementation in Modern Standard Arabic.

Simple past action. Such an action expresses an action that took place before the moment of speech. Denoting the past act, the form fa 'ala is indifferent to the nature of the action and can express both perfect and imperfect actions. Only the context and, more rarely, the lexical meaning of the verb, but not its form, make it possible to determine the nature of the action: ${ }^{15,16}$ zaharat alfajawāt al-kabìra al-manhūta fì al-jabal 'alā 'aydī al-masājīn - Large cracks appeared in the mountain that were hewn by the hands of prisoners.

An action that has taken place in the past and is related to the moment of speech. Usage of the form fa' ala with the particle qad expresses the fact that the action happened in the past which is near to the present ${ }^{17}$, noting that the action



The same function is performed by the form fa 'ala of the verbs of mental activity and sensory perception ${ }^{18}$, indicating the perfect nature of the action: na 'am, fahimtu kulla šay' yā 'ustād $\bar{d} \bar{l}$ - Yes, I understood (or have understood) everything, my teacher! At the same time, the expression of the perfect is not the main function of the verb form fa 'ala, since it coexists with a limited group of lexical verbs in a certain speech situation.

If, however, the prefix la precedes the particle $q a d$, and the particle receives the form laqad, then there is an increase in confidence about the performance of the action expressed by the verb form fa ala $^{19}$ When the sentence in general refers to the past, the usage of the particle qad with the connector $w a$ and the form of the past tense indicates the precedence of this action in relation to other

\footnotetext{
${ }^{15}$ AL-MI'MAR, Sh. Contrastive and comparative study of tenses in English and Arabic languages. In Ahlulbait jurnal, 2016, Vol. 20, pp. 6-27.

${ }^{16}$ OUIDED, S. Problems in translating tenses from English into Arabic. The present perfect: A case study, p. 29.

${ }^{17}$ Ibid, p. 27.

18 ABOUDI, J. H. A text-based model for the disambiguation of the temporal interpretation of the verb in Modern Standard Arabic, p. 61.

${ }^{19}$ Ibid, p. 72.
} 
past actions: ${ }^{20}$ qara'tu al-kitāb wa-qad bada'at al-layla - I read the book when the night had started. This communicative situation belongs to the past perfect (pluperfect) tense frame.

Continuous action in the past or an action that has taken place in the past many times. To implement such a communicative situation the past continuous tense kāna yaf'alu is used. For example: kānat Miṣr ta 'išsu 'āna'id 'ahdan zāhiran min al-rahā', wa-l-quwwa al-siyāsīya, fì 'ahd al-sulțān al-mamlūkī-At that time, during the reign of the Mamluk Sultanate, Egypt was living through a great era of prosperity and political power.

Another communicative situation is that in which the utterance indicates $a$ continuous action that began before another action in the past and was still going on at the time of this other action. Since this tense construction, in addition to time indication of the action, constantly points to the nature of the action (aspect), it can be considered an aspectual-temporal form.

In addition, continuous action in the past in the Arabic language is expressed by the analytical construction kāna fà 'ilan. In this case the auxiliary verb kāna is conjugated but the active participle, acting in the role of the semantic verb, agrees with the subject in gender and number and is always in the accusative case. For example: wa-kāna "nāhit" wāqifan ka-l-jabal al-šāhiq... - "Nakhit" was standing like a high mountain ...

Unlike the construction kāna yaf'alu, which expresses either a continuous or a multiple action, the participial construction kāna fä'ilan expresses a continuous action not as a process but as a characteristic of the subject at a point in time. It should be emphasized that the temporal meaning, expressed by the active participle, is determined in most cases by the context. Moreover, the participle is not an independent form in Arabic tense system.

A timeless action. Normally this is a general action that is not bounded by time limits, so it is indifferent to any particular timeline. Arabic proverbs, sayings, maxims function in such typical situations, because they are aimed at teaching children to understand different values, such as patience, work, success. In Arabic, the form of the past simple tense fa 'ala is always used to express this type of action. For example: man zara'a alšar hașada alnidāma - He who sows evil reaps repentance; man naẓara fí 'ayb nafsih 'ištagiala 'an 'ayb gayrih Those who see their own vices are not interested in others. Such an abstract, indefinite action, expressed in the form of the past simple tense, may relate to all time planes.

A future action from the past reference point. Some linguists also distinguish in the field of the past the analytical structure of the future-in-the-past tense -

${ }^{20}$ GRANDE, B. M. Kurs arabskoj grammatiki v sravnitel'no-istoricheskom osveschenii [A course of Arabic grammar in comparative-historical interpretation], p. 153. 
Representation of Time in Typologically Different Languages: A Functional Approach

kāna sa-yaf'alu, indicating that it is used extremely rarely and denotes an action that relates as future to the moment in the past or any past action. ${ }^{2122}$ However, the analysis of the illustrative material brings up no cases of the functioning of this construction. Moreover, even in modern grammars the future-in-the-past tense is not distinguished.

The past perfect (pluperfect) tense frame. In Arabic we find one communicative situation in this frame: a past action, completed before another past action. This action precedes a certain action in the past, or past action, the consequences of which are related to the following actions. The general formula of the pluperfect (past perfect) looks like this: kāna qad fa 'ala. In this case, the verb form expresses not only the temporal sequence of actions, but also the cause-and-effect relationship between them, and it is analogous to the English past perfect. ${ }^{23}$ For example: kānat sā 'at al-mașna ' qad 'a 'lanat intih à' fatrat al'istirāhạ, lakin 'ahadan min al- 'ummāl lam yabrah makāna-hu... - The factory clock had announced the end of the break, but one of the workers didn't leave his place.

Much less frequently, the analytical structure of the pluperfect functions in communicative situations of expressing an action that has taken place long ago and is not connected with other actions in the past, and an action that has taken place recently before the moment of speech ${ }^{24}$ that is the past tense frame.

The future tense frame. The universal linguistic category of the future has wide semantic boundaries and a number of additional meanings, such as modal meanings of desire, urge, limitation and division of time segment (the concept of "near future", "distant future"), etc.

An action that will take place in the future and is not necessarily after the moment of speech (simple future action). It is a future action that does not have precise detail: it expresses both perfect and imperfect action, depending on the context and, more rarely, the lexical meaning of the verb. Simple future action is conveyed through the forms sa-yaf'alu and sawfa yaf'alu where the particle

${ }^{21}$ MAMEDALIYEV, V. M. Ogly. Kategoriya vremeni, litsa $i$ nakloneniya $v$ sovremennom arabskom literaturnom yazyke kommunikatsii [The category of time, person and mood in the modern Arabic literary language of communication].

${ }_{22}$ PETROVA, Y. I. Systema chasovykh analitychnykh diyeslivnykh form $\mathrm{v}$ yehypets'komu dialekti arabs'koyi movy [The system of temporal analytical verb forms in the Egyptian dialect of the Arabic language]. In Oriental Studies, 2009, Vols. 45-46, pp. 81-91.

${ }^{23}$ Ibid.

${ }^{24}$ MAMEDALIYEV, V. M. Ogly. Kategoriya vremeni, litsa $i$ nakloneniya $v$ sovremennom arabskom literaturnom yazyke kommunikatsii [The category of time, person and mood in the modern Arabic literary language of communication], p. 25. 
$s a$ - or the separate particle sawfa before the form yaf'alu, limits the meaning to the future only. For example: sa-naftatihu mahallan li-širā' wa-bay 'ibtisāmāt al-mas'ūlīn wa- l-mašāhìr - We will open a store to buy and sell "smiles" (masks) of officials and celebrities.

According to Arab grammarians ${ }^{25}$, an action expressed by the type sawfa $y a f^{\prime} a l u$ refers to a more distant future, whereas $s a$ - is used to denote immediate action. Such an interpretation does not find confirmation in the facts of Modern Standard Arabic. Both types of particle appear as variants of the same form. An analysis shows that the usage of the conjugate particle $s a$ - is much more common than the usage of the particle sawfa.

An action that will have been taking place in the future (future continuous action). Such a communicative situation suggests that the action will take some time and is implemented with the help of a rare analytical construction yakūnu

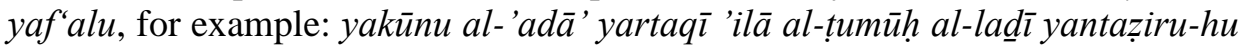
al-ša 'b min-hu ... -Activities will have been moving in the direction that people expect....

The future perfect tense frame. In this frame we encounter only one typical communicative situation - a future action that must occur and finish before the beginning of another future action or till a certain time in the future (future perfect action). This communicative situation is also about an action the consequences of which contribute to the realization of another future action ${ }^{26}$. The above-mentioned situation is implemented with the help of a rare analytical construction (sa)yakūnu fa'ala / qad fa'ala, for example: fì al-'intihābāt alqādima 'akūnu qad 'akmaltu 26 'āman fì al-ri'āsa, wa-l-'umr sa-yakūnu 71 'āman ... - In the next election, 26 years of my presidency will have ended, I will turn $71 \ldots$

When used without correlation with other future actions, this construction is used in a typical communicative situation of future action with a hint of possibility, guessing that is the future tense frame.

The results of the research show that throughout its historical development the category of aspect in Arabic has been weakening, resulting in an increase in the number of tense forms (constructions) in Modern Standard Arabic. Defining the most common forms of the verb in the present, we have the absolute

${ }^{25}$ AL-SAIDAT, E., AL-MOMANI, I. Future markers in Modern Standard Arabic and Jordanian Arabic: A contrastive Study. In European Journal of Social Sciences, 2010, Vol. 12, No. 3, pp. 397-408.

${ }^{26}$ SHARBATOV, G. Sh. Arabskij literaturnyj yazyk, sovremennyye arabskiye dialekty i regional'nyye obikhodno-razgovornyye yazyki [The Arabic literary language, modern Arabic dialects and regional everyday spoken languages]. In Languages of Asia and Africa, 1991, Vol. IV, No. 1, pp. 250-330. 
Representation of Time in Typologically Different Languages: A Functional Approach

dominant - the form of the present simple tense yaf'alu, which is most often used and is the leading tense form in various typical communicative situations. The usage of this tense form is not limited, as it expresses any action that takes place or a current state. The verb form of the past simple tense fa 'ala is dynamic and narrative. In contrast to the form of the past simple tense, complex tense constructions are static. The form of the future simple tense has only a temporal semantic. In general, verb forms of the future tense are used less frequently than verb forms of the present and the past tenses.

But besides all the communicative situations described above there are many more other communicative situations as in this article we describe only the direct functioning of verb tense forms without analyzing modal parameters, internal time, figurative realization, etc.

\section{Time (temporality) in Mandarin Chinese}

\section{Inventory of Means and Structure}

Mandarin Chinese is recognized as being a language that has essentially no inflections and "it is quite striking in its general lack of complexity in word formation" ${ }^{27}$; that is, unlike most European languages, the category of time in Chinese is represented by a system of multilevel indicators, as there is no grammatical tense. Although the verb itself in Chinese lacks a grammatical way of expressing time, i.e. lacks tense morphology, there are other lexical means or contextual information which help to provide information about the time of event. Mandarin does not manifest a high degree of morphological complexity and so the verb structure does not contain any expression of tense, aspect, voice, etc., so it must be appropriately framed to function as a finite verb in the sentence, and the framing can be either grammaticalized, or be lexical and syntactic. $^{28}$

Such a conception of the category of time in Mandarin Chinese is based primarily on the peculiarities of the Chinese picture of the world - that is to say, the concepts of time and space interact closely as they are represented by antonymic pairs of locatives, such as shàng above - xià below; lái to come - qù to go, etc. It may be assumed that time in Mandarin Chinese is perceived as a system in which the past and the future are fixed, and the present is a moment of

${ }^{27}$ LI, C. N., THOMPSON, S. A. Mandarin Chinese. A functional reference grammar, p. 11.

${ }^{28}$ DRAGUNOV, A. A. Issledovaniya po grammatike kitajskogo yazyka [Studies on the grammar of the Chinese language], p. 127. 
speech or a point of reference in time (xiànzài 'now'). Therefore, the pair "guòqù 'past' - jiānglái 'future"" is opposed to the present (xiànzài 'now'), because if there is no present, there can be neither past nor future. ${ }^{2930}$ There is still some controversy surrounding research into the category of time in Chinese. It is worth noting, that due to the multifunctionality of means that can express time in Mandarin Chinese, there are now attempts to present the category of time as a complex unity, consisting of the future and non-future frames (jiānglái shí, fêi jiānglái shí / 'future and non-future tense'). ${ }^{31,32,33}$ Thus, events can be conditionally divided into those belonging to the so-called yirrán 'already' category (i.e. "something has already happened or has started to happen") and the so-called wèirán 'not yet' category (i.e. "something has not yet happened").

Many studies ${ }^{34}$ currently debate how the category of time is exactly represented in Mandarin Chinese, as many researchers suggest a tenseless analysis, so this particular area remains unclear, as there is no exact opinion on the appropriate characteristics of this category. In light of this we can say that Chinese tends to focus on "inner time", in which the aspect of an action is emphasized. The language does not use verb affixes to signal the relation between the time of the occurrence of the situation and the time that situation is verbalized. ${ }^{35}$ It can be said that time in Mandarin is represented by certain aspectual-temporal categories with multilevel means of expression of this semantics, which operate as temporal indicators under certain contextual conditions. The system of Chinese aspectual affixes, the zero form of the verb (bare verb), various time nouns and adverbs, syntactic constructions, as well as

${ }^{29}$ Ibid., p. 38.

${ }^{30}$ LÜ, Sh.-X. Ocherk grammatiki kitajskogo jazyka. Chast' pervaja. Kategorii [Essay on the grammar of the Chinese language. Part one. Categories], p. 160.

${ }^{31}$ JING, Cheng 竟成. Hanyu shijian yuan lilun gang 汉语时间原理论纲 [Outline of the original theory of Chinese time]. In Jing Cheng (ed.). Hanyu shiti xitong guoji yantaohui lunwenji 汉语时体系统国际研讨会论文集 [Proceedings of the International symposium on the Chinese aspect system], pp. 1-11.

${ }^{32}$ HUANG, N. Z. On syntactic tense in Mandarin Chinese. In TAO, Hongyin, LEE, YuHui, SU, Danjie (eds.). 27th North American Conference on Chinese linguistics (NACCL-27), 2015, Vol. II, pp. 406-423.

${ }^{33}$ YUAN, L.-R., GUO, Sh.-W, WANG, J. 袁莉容，郭淑伟，王静. Xiandai hanyu juzi de shijian yuyi fanchou yanjiu 现代汉语句子的时间语义范畴研究 [Study on the semantic category of time in sentences in modern Chinese], pp. 87-105.

${ }^{34}$ LIN, J.-W. Time in a language without tense: The case of Chinese. In Journal of Semantics, 2006, Vol. 23, No. 1, pp. 1-53.

${ }^{35}$ LI, C. N., THOMPSON, S. A. Mandarin Chinese. A functional reference grammar, p. 184. 
Representation of Time in Typologically Different Languages: A Functional Approach

the communicative intention of an utterance together form a complex category of time with aspect-temporal subcategories (frames), which can be logically represented in the language as the frames of present, past and future time. It should be noted that the means of expression of the category of time in Mandarin Chinese have a high degree of lexicalization, and the contextual conditions play a determining role in the expression of time in speech.

By contextually pointing to present time the zero form of a verb can be used to address situations that occur in present time; in addition, the aspect markers zhèng, zài and zhe can be used. The progressive marker zài in front of the verb marks a dynamic situation that continues and has no beginning or end point; it is an unbounded, on-going event. ${ }^{36}$ If such a sentence does not have any time adverbs or other indicators that relate to a certain time, then the process is considered to coincide with the moment of speech, and attention is given to the moment of duration of an action at present ${ }^{37,38}$, as illustrated here: Tã zài chàng $g \bar{e}-\mathrm{He}$ is singing now. However, the explication of this marker and its use generally relies on context and depends on whether the speaker wants to emphasize that the subject is engaged in some activity at that time. A stative affix zhe follows a verb and focuses on a certain state or characterizes an object that is in a certain state ${ }^{39}$. In such situations, like another imperfective marker

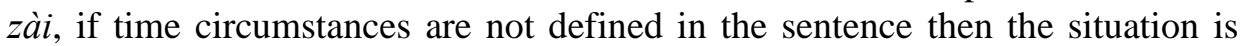
considered to be related to the moment of speech and occurs in the present time, as in the following sentence: Nù kàn, shüjià shang fàngzhe jì běn shü-Look, there are some books on the bookshelf. The progressive marker zhèng in front of a verb emphasizes the synchronicity of an action and the moment of speech (on the event in the middle of its happening), thus, the verb followed by this preverbal morpheme expresses an ongoing event or a durative situation, and the situation as a whole in the sentence can be related to the present time. ${ }^{40}$

\footnotetext{
${ }^{36}$ LIU, M.-Ch. Tense and aspect in Mandarin Chinese. In William S-Y. Wang and Chaofen Sun (eds.). The Oxford handbook of Chinese linguistics, p. 285.

${ }^{37}$ Ibid., pp. 283-285.

38 TAN, A.-Sh. Problemy skrytoj grammatiki: sintaksis, semantika i pragmatika jazyka izoliruyuschego stroya (na primere kitajskogo yazyka) [Problems of hidden grammar: Syntax, semantics and pragmatics of the isolated language (on the example of the Chinese language)], p. 357.

${ }^{39}$ YUAN, L.-R., GUO, Sh.-W, WANG, J. 袁莉容，郭淑伟，王静. Xiandai hanyu juzi de shijian yuyi fanchou yanjiu 现代汉语句子的时间语义范畴研究 [Study on the semantic category of time in sentences in modern Chinese], p. 288.

${ }^{40}$ TAN, A.-Sh. Problemy skrytoj grammatiki: sintaksis, semantika i pragmatika jazyka izoliruyuschego stroya (na primere kitajskogo yazyka) [Problems of hidden grammar:
} 
The past time situations can also be expressed in speech by several aspect markers: the perfective affix -le and the experiential affix -guo. A verb marked by the perfective marker -le expresses a simple, bounded action where the time of the event precedes the moment of speech. The experiential marker -guo indicates a past, discontinued situation which no longer holds in place or time, with a certain experience having been obtained as a result.

Along with aspect markers, past time can be represented in speech by the use of time adverbials, such as qùnián, zuótiān, céngjīng, etc., which can denote the time frame through their lexical meaning.

Future time is expressed in Mandarin Chinese by a number of multilevel means, such as the morpheme jiang ${ }^{41}$, the modal verbs yào and huì, time adverbials, several syntactic constructions ${ }^{42}$, as well as the zero form of telic verbs or verbal predicates with limited telicity. ${ }^{43}$ Along with modal verbs, the "potential mood" of the verb indirectly points to the future, for example: $T \bar{a}$ zuòdeliăo - He can do it. Such time adverbs as míngtiān, xiàwŭ, etc. play a key role in the expression of future-time situations, as they can indicate future time in the sentence on their own through their lexical meaning without any grammaticalized morphemes. For example: Wǒ míngtiān qù huǒchēzhàn jiē péngyou. - I'm going to the railway station tomorrow to meet a friend. In addition there are such adverbs as likè, lijji, jikěe, măshàng, jiù, gănkuài, gănjǐn, limă, etc.

Sometimes the communicative type of an utterance or a certain syntactic construction can also be an indicator of future time ${ }^{43}$, for example in sentences with imperative modality the verb can lack any grammatical affix but still indicate that the situation refers to the future, as in: Nĭ gănkuài zŏu! - Hurry up!

Although the above information gives only a general idea of the structure of the category of time in Mandarin Chinese, it is sufficient for understanding the specificity of this category in Chinese as a complex aspectual-temporal

Syntax, semantics and pragmatics of the isolated language (on the example of the Chinese language)], p. 371.

${ }^{41}$ HUANG, N. Z. On syntactic tense in Mandarin Chinese. In TAO, Hongyin, LEE, YuHui, SU, Danjie (eds.). 27th North American Conference on Chinese linguistics (NACCL-27), 2015, Vol. II, p. 406.

42 YUAN, L.-R., GUO, Sh.-W, WANG, J. 袁莉容, 郭淑伟，王静. Xiandai hanyu juzi de shijian yuyi fanchou yanjiu 现代汉语句子的时间语义范畴研究 [Study on the semantic category of time in sentences in modern Chinese], p. 97-98.

${ }^{43}$ TAN, A.-Sh. Problemy skrytoj grammatiki: sintaksis, semantika i pragmatika jazyka izoliruyuschego stroya (na primere kitajskogo yazyka) [Problems of hidden grammar: Syntax, semantics and pragmatics of the isolated language (on the example of the Chinese language)], p. 476. 
Representation of Time in Typologically Different Languages: A Functional Approach

structure. To further clarify this overview, more detailed information about the functioning of time markers in Mandarin Chinese is given below in the following subsection.

\section{The functioning of means of expressing time in Mandarin Chinese}

According to the above analysis of the structure of the category of time in Mandarin Chinese and the means and ways of its expression in speech, we may interpret this category as a complex aspectual-temporal structure with communicative situations that can conditionally be divided into three frames: 1) the present time frame (the action coincides with the moment of speech or occurs in present time); 2) the past time frame (the action precedes the moment of speech or occurs in past time); 3) the future time frame (an action will happen / may occur after the moment of speech or in future time). These frames are complex structures, expressed in speech by various aspect markers, time adverbs and other lexical means. In this article we focus on the peculiarities of syncretic expression of absolute and internal time in Mandarin Chinese, since more comprehensive studies require a wider format of research. It should be noted that in the proposed study we took into account the multifunctionality of aspect indicators and the dependence of their functioning on contextual framing.

The present time frame. We start with the analysis of the frame of present time, as it is generally considered to be an "actual reference point" ${ }^{\text {" } 44}$ for the speaker and the listener. Therefore, time is often unmarked at this time coordinate, as it is usually expressed by the zero form of the verb, if it is not in communicative focus. Present time in Chinese people`s understanding doesn't need to be expressed by any specialized grammar markers, as the action coincides with the moment of speech. Moreover, the contextual framing also plays a powerful role here. More detailed analysis of typical communicative situations of the frame of present time is given below.

An action happening at the moment of speech. This kind of action is usually expressed in speech through the zero form of the verb, and if there are no time markers or appropriate context, the situation is considered to happen at the moment of speech: Wó chī fàn. - I'm eating.

An action that takes place in the present (broad) time interval, not necessarily at the moment of speech. This kind of event is irrelevant to specific

44 TAN, A.-Sh. Problemy skrytoj grammatiki: sintaksis, semantika i pragmatika jazyka izoliruyuschego stroya (na primere kitajskogo yazyka) [Problems of hidden grammar: Syntax, semantics and pragmatics of the isolated language (on the example of the Chinese language)], p. 490. 
indications of the moment of speech or time interval, since it simply happens in present time and is represented by the zero form of a verb or an adjective. In addition, present time in such communicative situations can be indicated by lexical means (e.g., words denoting time). For example, Māmā zhè jŭ tiān juéde hěn bú shüfú. - Mum is feeling pretty bad these days.

An unbounded, ongoing event (present continuous time). The present continuous tense can be expressed in Mandarin Chinese by a special marker, the stative affix - zhe. A verb, framed by this suffix, expresses the state of an action, but not a result or change of this particular action, as in: Chuānghù dōu kāizhe. All the windows are open. If the speaker wants to emphasize not only the condition of a particular person or object defined by the subject, but also the fact of its existence or presence, a form of inverted subject can be used: it must be placed after the verb framed by the stative affix, as in the following example: Hòubian zhànzhe yī gè rén. - There is a person standing behind.

Another kind of expression of an ongoing event is formed by the use of the progressive marker zài in front of the verb. The verb can be also framed by the stative affix - zhe, so both markers can be used either together or separately, as in: Tà zài chìzhe fàn. - He is eating [now]. However, a speaker cannot express the state of an action or emphasize its continuity only by framing a verb with the progressive marker zài. In addition, the state of an action can be expressed through the form of the perfective aspect: the perfective marker le frames a verb or an adjective. Thus, the verb / adjective not only indicates an action or a change of state (quality) in the past, but also indicates the state of a subject, which is a result of this action or change. For example: Xiăo Zhāng gāng huilaile. - Xiao Zhang just got back [and is here now].

An action, that occurs regularly, continuously or repeatedly, or is a habit. Such an action occurs continuously, is constantly available, or is repeated, or is inherent in a particular person or object and is a characteristic feature of this person or object. For example: Tā dāng fänyì. - He is an interpreter. Such an action is also expressed through the zero form of a verb; words denoting time (měi tiān, cháng cháng) can also be quite often used to indicate time in such kind of sentences: Yéyé měi tiān lái zhè ge gōngyuán. - Grandfather comes to this park every day.

A timeless action. In such situations, facts of eternal truth, habits, character traits, laws are presented; they do not depend on the past, present or future. It is usually expressed by the zero form of a verb. Here are some examples of timeless actions: 1) Tàiyáng cóng dōng fāng shēngqǔ. - The sun rises from the east. 2) Wǒ xĭhuān măi dōngxi. - I like to buy things.

The past time frame. As can be seen from the analysis above, the characteristic feature of Mandarin Chinese is the more detailed expression of how an action proceeded in time or what the speaker`s attitude is towards the 
Representation of Time in Typologically Different Languages: A Functional Approach

situation, etc. The frame of past time can be expressed in speech by perfective, experiential, progressive, stative aspect-temporal markers, which characterize an action in terms of its completeness / incompleteness, its duration, etc. Past time can also be explicitly expressed in the utterance by the use of time adverbials. The following section is devoted to the description of the typical communicative situations of past time, as well as the basic means of its expression in speech.

An action that took place in the past, not necessarily right before the moment of speech. This kind of situation is usually expressed by the zero form of a verb, by using time adverbials or simply through the context. In such situations, the focus is not on the completeness / incompleteness of an action or its duration, but is on the fact that an action happened in the past, and it can be represented as follows: 1) Wǒ zuótiān wănshàng kàn diànshì. - I watched TV last night; 2) Nǐ shàng ge xīngqī qù năr? - Wǒ qù Běijīng. - Where did you go last week? - I went to Beijing.

A simple, closed, bounded action. This is a simple, closed event, where the time of the event precedes the time of speaking. The event is therefore, viewed as bounded with temporal, spatial or conceptual limits on it, as in the following example: Wǒ děngle yīhuìr. - I waited for a while. This kind of action is represented in speech by a verb framed by the perfective suffix -le. The sentence can also contain time adverbials to indicate time, as shown in the following example: Tā qiántiān xiěle yì piān wénzhāng. - He wrote an article the day before yesterday. Particular attention should be paid to verbs with inherent bounded meaning, in which the very meaning is the end of an action and which are the idiosyncrasy of Mandarin Chinese. ${ }^{45}$ For example, 1) Tă sĭle. - He died. 2) Wó wàngle. - I forgot. Adjectives in Mandarin also have this structural feature of formation of the perfective meaning. Such a situation indicates that a certain quality had certain changes in the past and also shows the condition (quality) of the subject, which is the result of these changes: $T \bar{a}$ liăn hóngle. - She blushed.

A completed, perfective action. A completed action conveys an idea of completion, which is represented in the utterance by resultative verb complements the meaning of which is connected with the completeness of an action and its certain result, in addition to the framing of the complex verb by the perfective suffix -le. In such situations, the speaker may also use time adverbials to indicate that an action took place in the past: Wǒmen wèi zhè cì yùndònghuì zuòhăole yīqiè zhŭnbèi. - We have got everything ready for this sports meet. The lack of completion in the past is expressed by negative adverb

${ }^{45}$ LI, C. N., THOMPSON, S. A. Mandarin Chinese. A functional reference grammar, p. 196. 
méi (méi yǒu) in preposition to the verb, for example: Wó méi zuò zuòyè. I didn't do my homework.

A discontinued action that took place at an uncertain moment in the past (indefinite past). Such a situation describes an action that took place at an undefined moment in the past and is not directly related to the present moment or the moment of speech. ${ }^{46}$ In such cases, an action is expressed by a verb framed by the experiential suffix -guo. Thus, it refers to a past, discontinued experience, and the situation no longer holds in place or time. Unlike a simple, bounded event, this kind of action is understood as one that took place at a certain point in the past without specific reference to the moment of time, and as a result there is some experience gained: Wŏ chīguo kăoyā. - I have eaten roast duck before. Such adverbs as yìjing, céngjīng, céng etc can be usually used to denote time, for example, Wò céngjīng qùguo Shànghăi. - I have been to Shanghai before.

An unbounded, ongoing action that took place in the past (past continuous). This situation describes an action that took place at some point in the past, and is described not as a moving or changing one, or following one after another, but as a certain state with a certain time reference. Usually, these are complex sentences where the marker -zhe either indicates a state or the duration of an action in a subordinate clause, and the marker zài signifies an ongoing event in relation to a reference time ${ }^{47}$, as described in the following example: Wó zuótiān wănshàng tăngzhe kàn diànyìng. - I was lying down watching a film last night.

An action that started before the moment of speech, and at the moment of speech the process or final state continues. In such cases an action usually has a non-active state or is not controlled by the subject ${ }^{48}$ : Xià xué le. - It's snowing.

An action being a first event in a sequence and bounded by the subsequent event. In such situations after one event has taken place, another event happens or new state materializes, the first event is of interest as an unanalysed whole, and the speaker signals that its occurrence is bounded by the subsequent event: ${ }^{49}$ Tà láile, tāmen liă jiù zóule. - He came, and they both left.

${ }^{46}$ YAKHONTOV, S. Ye. Kategoriya glagola v kitajskom yazyke [The category of verb in Chinese], p. 121.

${ }^{47}$ ZHOU, M.-L. Tense / aspect markers in Mandarin and Xiang dialects, and their contact. In Sino-Platonic Papers, 1998, Vol. 83, pp. 1-21.

${ }^{48}$ TAN, A.-Sh. Problemy skrytoj grammatiki: sintaksis, semantika i pragmatika jazyka izoliruyuschego stroya (na primere kitajskogo yazyka) [Problems of hidden grammar: Syntax, semantics and pragmatics of the isolated language (on the example of the Chinese language)], p .402.

${ }^{49}$ LI, C. N., THOMPSON, S. A. Mandarin Chinese. A functional reference grammar, p. 198. 
Representation of Time in Typologically Different Languages: A Functional Approach

Past instant time. This situation points to a single action in the past that started and ended very quickly. It is expressed by the form "numeral $y \bar{\imath}+$ verb (adjective)" or by the delimitative form of the verb, as shown in the following example: 1) Tā xīnlì yì jīng, dàn biăomiàn shàng què réng shénsè zìruò. - He was taken aback, but managed to remain calm; 2) Tã yí kàn jiù huǒle. - He became angry upon seeing it. This kind of situation describes a rapid, abrupt, sudden action, or emphasizes the suddenness of the results of an action.

The future time frame. Future time is actually represented as something that has not happened yet (wèirán "not yet"), that is, it is an unrealistic action. Chinese understanding of the future time is associated with the subjective perception of a particular situation, so it is often implemented in speech through modal verbs of opportunity, need, desire, urge, or through modal adverbs. Even the use of an unformed verb to express future time is an indicator of illocutionary force. Therefore, such settings should reflect the speaker's attitude to reality. In addition, the communicative type of an utterance can also serve as an indicator of future time, as in case of imperative situations. Below we describe the typical communicative situations of future time, as well as the basic means of its expression in speech.

Immediate future (present-to-future) time. This situation is related to an action, which is expected to happen or will happen right after the moment of speech or is expected or is about to take place in the near future. Grammatically this kind of an action is often expressed in speech through the zero form of a verb, for example: Xiăo Zhāng qù kāfêitīng. - Xiao Zhang will go to the cafe. Although utterances of this type are grammatically independent, the use of this form to express future time has illocutionary force, as the speaker tends to use it by answering a question or confirming that a certain event will happen. In addition, the speaker stresses a verb by intonation, thereby putting emphasis on answering questions or confirming certain information, as shown in the example: Tă zuò zhè jiàn shì. - He will do this task. If a certain action is not going to take place in the future, then the situation is expressed in the utterance by a negative adverb bù in front of the corresponding verb: Wó bú qù. - I'm not going.

Imperative situations can also indicate an action, that is expected to be fulfilled, since such an action is unreal at the moment of speech. ${ }^{50}$ For example, Nǐ gàosu Xiăo Zhāng zăo diănr lái. - Tell Xiao Zhang to come a bit earlier.

Based on the fact, that time can be represented in speech without any appropriate affixes, an action that will happen immediately after the moment of speech can be explicitly expressed by such adverbs of time as măshàng, jiù, likè, which have the meaning of immediateness.

${ }^{50}$ LI, C. N., THOMPSON, S. A. Mandarin Chinese. A functional reference grammar, p. 475. 
Also, an action that is expected to happen in the near future can be implemented through a verb phrase consisting of an auxiliary and a verb. However, the choice of this form by the speaker is based on his/her desire to clarify the mood of utterance. For example, Wǒ gāi zŏu. - I should go.

An action that will take place in the future, not necessarily after the moment of speech. Such an action indicates the normal situation that will occur in the future, no matter at what exact point in the future. It can be expressed through the zero form of a verb, sometimes accompanied by such adverbs as cái, jiù, time adverbs mingtiān, hòu nián, etc. For example, Tā mingtiān zăoshang cái huilái. - He will come back only tomorrow morning.

An unbounded, ongoing event, that will happen in the future period of time (future continuous). The situation of future continuous time indicates that an action will take place in the future and will last for a certain period of time. Like the present continuous time, such situations are expressed in speech by framing a verb with the stative affix - zhe alone or together with the progressive marker

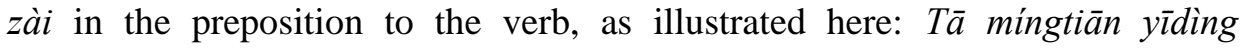
chuānzhe xîfú qù cānjiā huódòng. - He will definitely be wearing a suit to attend an event tomorrow.

An action, that will happen and be completed in the future (future perfect time). This situation indicates that an action will happen and be completed in the future; it can be expressed in speech by a special delimitative form, structurally represented by a verb reduplication, or reduplication of a verb plus the morpheme $y \bar{l}$ between the verb and the reduplicated syllable, while $y \bar{\imath}$ and the reduplicated syllable form a quantity adverbial. For example, 1) Wó xiān kăolü kăolü zhè ge wèntí. - I will first think over this question; 2) Wó kàn yí kàn, zài liánxì nĭ. - I will take a look and then contact you. A verb in a delimitative form is often used in imperative sentence, as shown in the following example: Nǐ shì shì - You try.

Future perfect time may also be presented as an action that will take place immediately after the moment of speech. However, the emphasis is put on the fact,that an action will be completed. In this case, the verb is framed with the perfective affix -le. For example, 1) Wǒ zóule. - I am leaving; 2) Láile láile. I'm coming. Sometimes such a situation is represented by an action that must be performed immediately to prevent danger or some urgent situation. It is expressed by a verb framed by the perfective suffix -le in the context of an order, so the speaker presents the situation as an action that has already been completed, as there is a certain need for its urgent fulfilment ${ }^{51}$, for example: Guānle tā! - Turn it off!

${ }^{51}$ Ibid., p. 209 
Representation of Time in Typologically Different Languages: A Functional Approach

An action that will take place in the future and is based on the speaker's knowledge, thoughts, intentions and desires. This situation is to some extent subjective, as it employs a subjective modality. By using the "potential mood" form and the auxiliaries, the speaker provides a subjective assessment of the information in the statement. Quite often the utterance is framed by the modal particles $d e, n e, b a$, etc., which emphasize or even independently indicate the mood of an utterance. For example, 1) Nǐ zuòdewán zhè jiàn shì. - You can finish this task; 2) Wǒ huì gàosù nì de. - I'll tell you.

Having analyzed the category of time in Mandarin Chinese, it can be seen that the aspectual-temporal markers that frame a verb or adjective may serve as grammaticalized indicators of time but they are polyfunctional to a certain extent. In such circumstances, more precise information about time is provided by lexical means or a context. The division of the category of time into frames in Chinese is optional to a certain extent, as we can see that the category of time in this language is represented by an aspectual-temporal complex, while the means of its expression do not simply indicate the time of an event, but focus mainly on the character, duration, completeness, perfectivity and boundedness of an action.

\section{Conclusions}

Turkish and Arabic, on the one hand, and Chinese, on the other hand, represent two diametrically opposing ways of expressing linguistic meaning, including the notion of time. There are many similarities on the level of the categorization of time which makes sense because the process of categorization stems from the fundamentals of human thinking. Nevertheless grammatical (or "nongrammatical" / non-grammaticalized as in Chinese) means for the expression of time differ, sometimes considerably. The present research makes it possible to distinguish the similarities and differences in the systems of denoting time in the three languages investigated on structural and functional levels in the form of a typology of linguistic means for the expression of time and a typology of temporal communicational situations.

Turkish and Arabic as languages of a synthetic grammatical type have a system of morphological (and syntactical in Turkish) means for denoting time. For the linguistic expression of total and internal time both Turkish and Arabic have a system of tense forms consisting of appropriate inflexions (Arabic) and suffixes (Turkish). However, it should be stated that the system of tense forms in Turkish is much more extensive than the one in Arabic: 38 Turkish tense forms can be contrasted with 10 tense forms in Arabic. 
Turkish tense forms are distinguished according to the parameters of the location of an action on a timeline as well as the emphasis on internal temporal and / or modal features of an action. In Turkish an action can be represented, for example, as past regarding the moment of speech or another past action, as present which takes place in or "around" the moment of speech, as future or located between the moment of speech and some future moment (the so-called pre-future or going-to-future action). It also can be represented as past progressive or factual, as timeless, as traditional for a certain group of speakers or habitual for an individual, etc. Moreover, in several cases the use of tense forms can be due to stylistic parameters: a certain form can be used or vice versa cannot be used in texts of certain functional styles (for example, the present tense cannot be used in official or scientific texts and, on the contrary, the present progressive tense can rarely be used in everyday speech or unofficial communication). Furthermore, the system of representation of a non-evident action merits a special focus; this includes a number of tense forms denoting an action the speaker has not witnessed and about which he / she makes a judgment based on the words of some other person(s).

Despite a significant number of tense forms and constructions in Arabic, the present simple tense and the past simple tense function most commonly in different communicative situations. The present simple tense is a verb form implying the aspectual meaning of process which is completely neutralized within a certain context to denote a future action. The most fundamental semantic feature of this form is the ambiguity of its "semantic scope"; it can denote a feature of a subject or object which cannot be measured in terms of time. The past simple tense is a verb form which is dynamic and narrative; it designates a set of actions which dynamically follow one another on a timeline from the past to the future. This tense form tends to convey the nuance of meaning of an internal limit at the same time. In contrast to the past simple the complex tense constructions (the past continuous, the future-in-the-past and the past perfect) are static; they are not often used, and the future-in-the-past form is hardly found at all. As regards the future forms, the future simple can be characterized as a purely tense form whereas the future perfect and the future continuous denote the completeness or continuousness of an action correspondingly i.e. they convey not only temporal (total time) but also aspectual (internal time) meaning. Generally, it can be said that the future forms are less functional than the past and present forms in Arabic.

The Chinese language presents a completely different, analytical type of expression of the linguistic meaning. In fact, Chinese does not have any grammatical means of denoting time and only offers several grammaticalized aspectual suffixes which make it possible to distinguish shades of meaning connected with internal time. However, the substantive spectrum of 
Representation of Time in Typologically Different Languages: A Functional Approach

communicative situations related to total time is denoted lexically. The category of time in modern Chinese is represented by a complex of aspectual and temporal subcategories which are referred to by means of polyfunctional aspectual markers, nouns and pronouns denoting time, syntactic constructions with the involvement of contextual information. These structural features of the category of time in Chinese make it evident that the aspectual (internal time) and modal characteristics of a given action are to the fore; continuousness, completeness / incompleteness, the stage of development of the action on a timeline are emphasized and the speaker's subjective perception of the given situation and modal features of the action must be taken into consideration. Context merits special attention since time is not explicated by means of a lexical meaning or a grammatical form in many cases but with the zero form of a verb within a certain context (for example, such communicative situations as "the action which takes place in the moment of speech", "the action which is expected to take place after the moment of speech", "the action which took place in the past") are denoted in this way. Thus, in many cases marking a verb with a special grammaticalized marker is optional when denoting temporal and aspectual characteristics of an action in modern Chinese.

The people (at least those who speak the languages which are the subject of this research) conceptually see the world similarly but the degree of detail in denoting time and therefore the ways and means of denoting time differ, sometimes significantly between Turkish, Arabic and Chinese. Undoubtedly, the main prospect which arises from this scoping paper is the need for a detailed investigation of temporal systems in each of the languages according to the functional approach with the aim of developing eventually a functional / communicative grammar of each language.

\section{REFERENCES}

ABOUDI, Jawad H. A text-based model for the disambiguation of the temporal interpretation of the verb in Modern Standard Arabic. PhD Dissertation. Greater Manchester: University of Salford, 1987.

AL-MI'MAR, Shaima'. Contrastive and comparative study of tenses in English and Arabic languages. In Ahlulbait jurnal, 2016, Vol. 20, pp. 6-27.

AL-SAIDAT, Emad, AL-MOMANI, Islam. Future markers in Modern Standard Arabic and Jordanian Arabic: A contrastive Study. In European Journal of Social Sciences, 2010, Vol. 12, No. 3, pp. 397-408.

ALASMARI, Jawharah, WATSON, Janet C. E., ATWELL, Eric. A contrastive study of the Arabic and English verb tense aspect: A corpus-based approach. 
In PEOPLE: International Journal of Social Sciences, 2018, Vol. 3, No. 3, pp. 1604-1615. doi: https://doi.org/10.20319/pijss.2018.33.16041615

BEESTON, Alfred F. L. Written Arabic: An approach to the basic structures. Cambridge: Cambridge University Press, 1968.

BONDARKO, Aleksandr V. Funktsional'naya grammatika [Functional grammar]. Leningrad: Nauka, 1984.

BONDARKO, Aleksandr V. (ed.). Teoriya funktsional'noj grammatiki: Temporal'nost'. Modal'nost' [Functional grammar theory: Temporality. Modality]. Leningrad: Nauka, 1990.

DRAGUNOV, Aleksandr A. Issledovaniya po grammatike kitajskogo yazyka [Studies on the grammar of the Chinese language]. Moscow, Leningrad: Izdatel'stvo Akademii nauk SSSR, 1952.

FISCHER, Wolfdietrich. Classical Arabic. In HETZRON, Robert (ed.). The Semitic languages. London: Routledge, 1997.

GRANDE, Bentsion M. Kurs arabskoj grammatiki v sravnitel'no-istoricheskom osveschenii [A course of Arabic grammar in comparative-historical interpretation]. 2nd ed. Moscow: Vostochnaya literature, 2001.

HENGIRMEN, Mehmet. Turkish grammar. Ankara: Publishing House Engin, 1999.

HUANG, Nick Z. On syntactic tense in Mandarin Chinese. In TAO, Hongyin, LEE, Yu-Hui, SU, Danjie (eds.). 27th North American Conference on Chinese linguistics (NACCL-27), 2015, Vol. II, pp. 406-423. California, USA: University of California Los Angeles.

JING, Cheng 竟成. Hanyu shijian yuan lilun gang 汉语时间原理论纲 [Outline of the original theory of Chinese time]. In Jing Cheng (ed.). Hanyu shiti xitong guoji yantaohui lunwenji 汉语时体系统国际研讨会论文集 [Proceedings of the International symposium on the Chinese aspect system], pp. 1-11. Shanghai: Baijia chubanshe, 2004.

KHRAKOVSKIY, Viktor S. Vidovremennyye otnosheniya $v$ sisteme lichnykh form glagola $v$ arabskom yazyke [Aspectual and temporal relations in the system of personal verb forms in the Arabic language]. PhD Dissertation. Leningrad: Leningrad Order of Lenin State University named after A. A. Zhdanov, 1961.

LEWIS, Geoffrey. Turkish grammar. 2nd ed. Oxford: Oxford University Press, 2001.

LI, Charles N., THOMPSON, Sandra A. Mandarin Chinese. A functional reference grammar. Berkeley and Los Angeles: University of California Press, 1989. 
Representation of Time in Typologically Different Languages: A Functional Approach

LIN, Jo-Wang. Time in a language without tense: The case of Chinese. In Journal of Semantics, 2006, Vol. 23, No. 1, pp. 1-53. doi: https://doi.org/10.1093/ jos/ffh033

LIU, Mei-Chun. Tense and aspect in Mandarin Chinese. In WANG, William SY., SUN, Chaofen (eds.). The Oxford handbook of Chinese linguistics. Oxford: Oxford University Press, 2015. doi: https://doi.org/10.1093/oxfordhb/ 9780199856336.013.0070

LÜ, Shuxiang. Ocherk grammatiki kitajskogo jazyka. Chast' pervaja. Kategorii [Essay on the grammar of the Chinese language. Part one. Categories]. Moscow: Nauka, 1965.

MAMEDALIYEV, Vasim Mamedali Ogly. Kategoriya vremeni, litsa $i$ nakloneniya $v$ sovremennom arabskom literaturnom yazyke kommunikatsii [The category of time, person and mood in the modern Arabic literary language of communication]. PhD Dissertation. Tbilisi: Tbilisi University, 1974.

OUIDED, Sekhri. Problems in translating tenses from English into Arabic. The present perfect: A case study. Master's thesis. People's Democratic Republic of Algeria: Mentouri university, 2008 - 2009.

PETROVA, Yuliya I. Systema chasovykh analitychnykh diyeslivnykh form v yehypets'komu dialekti arabs'koyi movy [The system of temporal analytical verb forms in the Egyptian dialect of the Arabic language]. In Oriental Studies, 2009, Vol. 45-46, pp. 81-91.

$\mathrm{ROSCH}$, Eleanor H. Principles of categorization. In ROSCH, Eleanor H., LLOYD, Barbara B. (eds.). Cognition and categorization. Hillsdale, New Jersey: Lawrence Erlbaum, 1978.

SHARBATOV, Grigorij Sh. Arabskij literaturnyj yazyk, sovremennyye arabskiye dialekty i regional'nyye obikhodno-razgovornyye yazyki [The Arabic literary language, modern Arabic dialects and regional everyday spoken languages]. In Languages of Asia and Africa, 1991, Vol. IV, No. 1, pp. 250-330.

SHCHEKA, Yurij V. Prakticheskaya grammatika turetskogo yazyka [Practical grammar of the Turkish language]. Moscow: Vostok-Zapad, 2007.

SOROKIN, Sergii V., TIMKOVA, Tetiana M. Problems and difficulties in teaching Turkish grammar to Ukrainian students at university level. In Journal of History Culture and Art Research, 2019, Vol. 8, No. 4, pp. 90114. doi: http://dx.doi.org/10.7596/taksad.v8i4.2294

TAN, Aoshuang. Problemy skrytoj grammatiki: sintaksis, semantika i pragmatika jazyka izoliruyuschego stroya (na primere kitajskogo yazyka) [Problems of hidden grammar: Syntax, semantics and pragmatics of the isolated language (on the example of the Chinese language)]. Moscow: Yazyki slavyanskoj kul'tury, 2002. 
YAKHONTOV, Sergeij Ye. Kategoriya glagola $v$ kitajskom yazyke [The category of verb in Chinese]. Leningrad: Izdatelstvo Leningradskogo universiteta, 1957.

YUAN, Lirong, GUO, Shuwei, WANG, Jing 袁莉容, 郭淑伟, 王静. Xiandai hanyu juzi de shijian yuyi fanchou yanjiu 现代汉语句子的时间语义范畴研 究 [Study on the semantic category of time in sentences in modern Chinese]. Chengdu: Sichuan University Press, 2010.

ZHOU, Minglang. Tense / aspect markers in Mandarin and Xiang dialects, and their contact. In Sino-Platonic Papers, 1998, Vol. 83, pp. 1-21. 